\title{
СОЦІАЛЬНІ ПРОБЛЕМИ ЗА УМОВ ПРОВЕДЕННЯ АНТИТЕРОРИСТИЧНОЇ ОПЕРАЦІї - ОПЕРАЦІЇ ОБ’ ЄДНАНИХ СИЛ НА ТЕРИТОРІЇ, ПІДКОНТРОЛЬНІЙ УРЯДУ УКРАЇНИ (ЛУГАНСЬКА ОБЛАСТЬ)
}

\author{
Н. М. Стешенко ${ }^{1}$, О. Н. Литвинова ${ }^{2}$ \\ ${ }^{1}$ Комунальне некомерційне підприємство Луганської обласної ради \\ "Луганська обласна клінічна лікарня" \\ ${ }^{2}$ Тернопільський національний медичний університет \\ імені І. Я. Горбачевського МОЗ Украӥни
}

\begin{abstract}
У статті висвітлено соціальні та гуманітарні проблеми, які стали наслідком військового вторгнення Російської Федерації на територію України. Показано катастрофічний стан внутрішньо переміщених осіб та структуру жертв серед цивільного населення.
\end{abstract}

\section{SOCIAL PROBLEMS IN THE CONDITIONS OF ATO-JOINT FORCES OPERATION ON THE TERRITORY WHICH IS CONTROLLED BY THE GOVERNMENT OF UKRAINE (LUHANSK REGION)}

\author{
N. M. Steshenko', O. N. Lytvynova ${ }^{2}$ \\ ${ }^{1}$ Municipal non-profit enterprise of Luhansk regional council \\ "Luhansk Regional Clinical Hospital" \\ ${ }^{2}$ I. Horbachevsky Ternopil National Medical University
}

\begin{abstract}
The article highlights the social and humanitarian problems that followed the military invasion of the Russian Federation on the territory of Ukraine. The catastrophic situation of internally displaced persons and the structure of civilian casualties are shown.
\end{abstract}

Вступ. Агресія Росії проти України оголила ряд серйозних економічних та соціальних проблем і одночасно стала причиною формування соціальноекономічних загроз, що переросли в надзвичайні ситуації соціально-політичного характеру [1].

Основна частина. Виникнення та розвиток конфлікту на сході України зумовили невпинне погіршення економічних показників розвитку Донецької та Луганської областей, що супроводжується також втратою частини активів. За даними Мінрегіону [2], лише за півроку збройного конфлікту, станом на 1 листопада 2014 р. у Донецькій та Луганській областях пошкоджено або зруйновано 227 об'єктів освіти, 48 - охорони здоров'я, 56 - культурного і спортивного призначення, 91 - адміністративні будівлі, 14 об'єктів торгівлі та 132 промислових об'єкта на загальну суму 5 млрд 788 млн грн (рис. 1). Без житла залишилось понад 710 тис. осіб. У Луганській області

(с) Н. М. Стешенко, О. Н. Литвинова, 2021 зруйновано та пошкоджено близько 690 житлових будинків. У результаті лише за цей період загальна сума економічних втрат України через бойові дії на Донбасі склала понад 30 млрд грн [3].

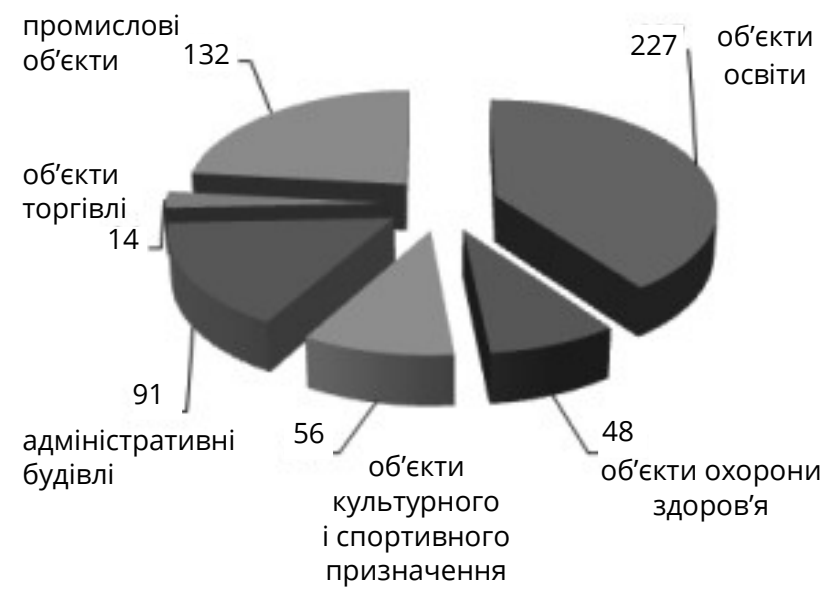

Рuc. 1. Кількість зруйнованих або пошкоджених об'єктів у Донецькій та Луганській областях станом на 01 листопада 2014 p. 
Проведення бойових дій на сході країни, крім економічних, спричинило також низку соціальних і гуманітарних проблем. По-перше, поява в Україні категорії внутрішньо переміщених осіб (ВПО), кількість яких за 275,3 тис. осіб, які вимушено покинули свої домівки через збройну агресію Російської Федерації. За даними інформації про стан виконання Плану заходів з реалізації в Луганській області Стратегії інтеграції внутрішньо переміщених осіб та впровадження довгострокових рішень щодо внутрішнього переміщення на період до 2020 р., за III квартал 2019 р. із зареєстрованих ВПО 72 \% це пенсіонери, 8 \% - діти, 3 \% - інваліди, $11 \%$ - особи працездатного віку і 2 \% тих, хто потребує працевлаштування [4].

Проте офіційна статистика не відображає реальних масштабів переселення, оскільки частина громадян покидає зону бойових дій самостійно (переїзд до родичів, знайомих, тощо без проходження реєстрації).

Характерним відображенням нинішньої ситуації $\epsilon$ зменшення розмірів доходів населення з усіма наслідками, які випливають із цього.

Конфлікт продовжує порушувати звичне життя цивільного населення і спричиняти загибель, по- ранення і руйнування. Періодичні сплески та спади у кількості загиблих і поранених серед цивільного населення відображають нестабільну ситуацію та стійку атмосферу незахищеності й тривоги, якими характеризується життя цивільних осіб по обидва боки від лінії зіткнення. За період з 16 травня до 15 серпня 2018 р. Управління Верховного комісара Організації Об'єднаних Націй з прав людини (УВКПЛ) зафіксувало на сході України 105 жертв серед цивільного населення (12 загиблих і 93 поранених), що на 30 \% більше порівняно з попереднім звітним періодом. Більшість із цих інцидентів припала на період із середини травня до кінця червня. 50 \% жертв були спричинені обстрілами або вогнем із легких озброєнь, причому більшість з них була зафіксована на території, яка контролюється озброєними групами, і може бути спричинена діями уряду (рис. 2).

Після 1 липня, коли набрало чинності «хлібне перемир'я», чисельність жертв серед цивільного населення значно скоротилася, демонструючи важливість узгоджених зусиль із забезпечення стійкого припинення вогню [5].

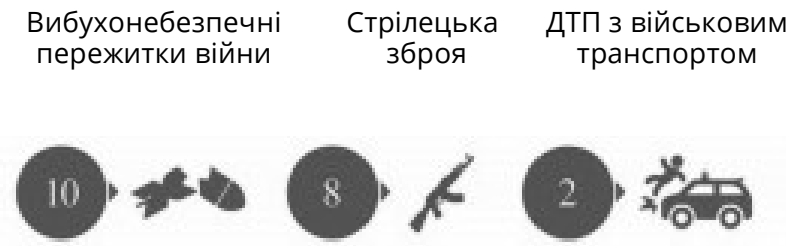

Рис. 2. Структура причин жертв серед цивільного населення.

Особливо негативна ситуація склалася для пенсіонерів. У першій половині звітного періоду уряд продовжив припиняти велику кількість пенсійних виплат [6]. Ця тенденція з'явилася після того, як у червні 2016 р. уряд запровадив процедуру, що вимагала проведення перевірки місця проживання пенсіонерів - ВПО. За період із квітня до червня 2018 р., кількість внутрішньо переміщених осіб, які отримували пенсію, скоротилася на 15 \%, з приблизно 562 тис. до 477 тис. У липні 2018 р. Кабінет Міністрів України прийняв Постанову № 548, згідно з якою частота проведення банками перевірок пенсіонерів внутрішньо переміщених осіб знову зросла з одного до двох разів на рік. Управління Верховного комісара Організації Об'єднаних Націй з прав людини застерігає, що вимога щодо перевірки ВПО кожні шість місяців буде пов'язана з ризиком стикнутися з проблемами щодо захисту, тому що цим особам дедалі частіше необхідно буде перетинати лінію зіткнення [5]. Ця нова вимога додається до вже існуючих обмежень для пенсіонерів ВПО, які ризикують втратити реєстрацію ВПО і, як наслідок, доступ до пенсій, якщо вони перебуватимуть на території, що контролюється озброєними групами, не виїжджаючи більше ніж на 60 днів або 90 днів за виняткових обставин [6].

3 травня 2018 р. Верховний Суд постановив, що припинення виплати пенсії ВПО, згідно з Постановою Кабінету Міністрів України № 365, становить неправомірне втручання у право власності [5].

Поки створення нової системи очікується, виконання постанови суду ще не забезпечено, особливо щодо перевірки місця проживання ВПО для визначення права на пенсію та соціальну допомогу.

Незважаючи на обмеження свободи пересування, велика кількість людей продовжує здійснювати небезпечну подорож через лінію зіткнення: у травні було зафіксовано 1142300 перетинів, у червні 1189 300, у липні - 128910 043. Порівняно з попе- 
реднім звітним періодом середньоденна кількість перетинів лінії зіткнення збільшилася на 5 тис. і досягла 39 тис. [5]. Таке збільшення, ймовірно, зумовлене поїздками пенсіонерів на контрольовану урядом територію для отримання пенсій, виплата яких раніше була призупинена.

УВКПЛ продовжує висловлювати стурбованість тим, що особи, які перетинають лінію зіткнення, а це переважно люди похилого віку та особи з медичними проблемами, наражаються на підвищені ризики смерті через стан здоров'я і небезпеку. Упродовж звітного періоду люди, які перетинають лінію зіткнення, зазнавали впливу високих літніх температур, не маючи при цьому доступу до належних санітарних споруд або медичних установ.

Проблема ВПО полягає ще й у тому, що на національному рівні поки відсутній механізм компенсації шкоди за втрачене майно на окупованій території. Люди вимушені поневірятися по судах, які найчастіше виносять рішення не на їх користь. Відшкодування можливо вимагати у країни-агресора за допомогою міжнародної інстанції - Європейського суду з прав людини [7].

Управління ДСНС у Луганській області повідомило УВКПЛ, що за період із 1 травня до 1 серпня за медичною допомогою звернулося 8847 осіб (у тому числі 414 дітей та 1162 особи з інвалідністю), що більше, ніж у попередні місяці. УВКПЛ не змогло отримати повні статистичні дані щодо кількості осіб, які звернулися за медичною допомогою, на тій стороні КПВВ, що контролюється озброєними групами. 17 травня 2018 р. померла жінка 77 років, 30 травня 2018 р. - чоловік 71 рік (відразу після перетину), а 19 липня 2018 р. - чоловік 79 років. 27 червня 2018 р. від серцевого нападу, стоячи у черзі на КПВВ «Майорське», помер чоловік 79 років. 11 серпня 2018 р. двоє чоловіків віком 50-60 років померли, намагаючись перетнути лінію зіткнення: одному стало погано в автобусі, який їхав через КПВВ «Мар'їнка», і він помер невдовзі після того, як вийшов з нього; другий помер, стоячи у черзі на цьому ж КПВВ [5].

Однією з найвразливіших проблем є діти, які опинилися в складних життєвих ситуаціях на територіях конфліктних дій. Статус «дитина, яка постраждала внаслідок збройної агресії і військових дій» був запроваджений за кілька років після початку конфлікту на сході. Але він нічого у житті дітей не змінює. Із заяв представників Міністерства соціальної політики України відомо, що чиновники хотіли провести загальну оцінку кількості пільговиків і потім визначити обсяг допомоги від держави, але конкретних термінів ніхто не називав [8]. Були спроби прирівняти дітей, які мають такий статус, до дітей Другої світової війни, але щось пішло не так у наших законодавців, і діти залишилися соціально незахищеними - без надання додаткових пільг чи гарантій. Лише, можливо, десь на місцевому рівні можуть претендувати на адресну допомогу - приміром, безкоштовне харчування у школі.

За офіційними даними, оприлюдненими Донецькою ОДА у серпні 2020 р., в Україні лише 20 \% від загальної кількості дітей-переселенців отримали статус постраждалих внаслідок воєнних дій та збройних конфліктів - 39 тис. У Дитячому фонді ООН (ЮНІСЕФ) говорять, що в Україні понад 400 тис. продовжують зазнавати серйозних ризиків для фізичного здоров'я і психологічного благополуччя через конфлікт на сході України. Діти різного віку ростуть в умовах безперервного конфлікту, мають психологічні травми і потребують постійної підтримки психологів. Однак досі не існує реального механізму, який би захищав таких дітей, відповідно до норм міжнародного гуманітарного права [9].

На території, яка контролюється «Луганською народною республікою», озброєні групи продовжували практику «превентивного арешту» на строк 30 діб, упродовж якого осіб тримають без зв'язку зі зовнішнім світом, не дозволяючи їм спілкуватися 3 адвокатами, а родичі не мають інформації про їхнє місцезнаходження. Така практика, що може бути рівносильна насильницькому зникненню, викликає серйозне занепокоєння щодо поводження із затриманими та умов тримання під вартою. Упродовж звітного періоду УВКПЛ отримало інформацію про осіб, яких тримали під вартою в порядку «превентивного арешту» від 30 до 64 діб у «міністерстві внутрішніх справ» та «МДБ» [5].

Висновки. 3 початку збройної агресії Російської Федерації проти України на Донбасі, за даними ООН, загинуло 3350 мирних жителів. За словами голови Моніторингової місії Організації Об'єднаних Націй з прав людини в Україні Матильди Богнер, понад 7 тис. цивільних зазнали поранень. [10]. Виходячи із вищенаведеного аналізу, бачимо, що мирне населення в час військового конфлікту страждає значно глибше і триваліше, захист і гарантії безпеки дуже умовні. Така ситуація вимагає якомога швидшого вирішення питань соціального забезпечення та якомога швидшого вирішення даного конфлікту. 


\section{СПИСОК ЛІТЕРАТУРИ}

1. Гаркавий С. Ф. Ескалація конфлікту на сході України: соціально-економічні наслідки [Електронний ресурс] / С. Ф. Гаркавий // Фінансовий простір. - 2014. № 4 (16). - Режим доступу : https://ofp.cibs.ubs.edu.ua/ files/1404/14gsfekn.pdf.

2. Офіційний сайт Міністерства регіонального розвитку, будівництва та житлово-комунального господарства України [Електронний ресурс]. - Режим доступу : http:// minregion.gov.ua/.

3. Офіційний сайт Інформаційно-аналітичного центру РНБО [Електронний ресурс]. - Режим доступу : http:// mediarnbo.org.

4. Інформація про стан виконання Плану заходів з реалізації в Луганській області Стратегії інтеграції внутрішньо переміщених осіб та впровадження довгострокових рішень щодо внутрішнього переміщення на період до 2020 року (за III квартал 2019 року) [Електронний ресурс]. - Режим доступу : https://dszn.loga.gov.ua/ upload/editor/plan_zahodiv_iii_kv.pdf.

5. Управління Верховного комісара Організації Об'єднаних Націй з прав людини : Доповідь щодо ситуації з правами людини в Україні 16 травня - 15 серпня 2018 року [Електронний ресурс]. - Режим досту- пу : https://www.ohchr.org/Documents/Countries/UA/ ReportUkraine16May-15Aug2019_UA.pdf.

6. Про забезпечення прав і свобод внутрішньо переміщених осіб : Закон України від 20 жовтня 2014 р. № 1706-VII [Електронний ресурс]. - Режим доступу : https://zakon. rada.gov.ua/laws/show/1706-18.

7. Вимушена переселенка довела у суді: залишила свій дім внаслідок збройної агресії РФ [Електронний ресурс]. - Режим доступу : https://helsinki.org.ua/articles/ vymushena-pereselenka-dovela-u-sudi-zalyshyla-sviy-dimvnaslidok-zbroynoi-ahresii-rf/.

8. Діти війни: статус - $є$, допомоги - нема [Електронний ресурс]. - Режим доступу : https://helsinki.org.ua/articles/ dity-viyny-status-ie-dopomohy-nema/.

9. 700 тисяч дітей в Україні не мають належнихумов для навчання через конфлікт на Донбасі : ЮНІСЕФ [Електронний ресурс]. - Режим доступу : https://www.radiosvoboda. org/a/news-unisef-dity-konflikty/29681185.html.

10. В ООН назвали кількість загиблих цивільних на Донбасі з початку війни [Електронний ресурс]. - Режим доступу : https://www.slovoidilo.ua/2020/03/12/novyna/ suspilstvo/oon-nazvaly-kilkist-zahyblyx-cyvilnyx-donbasipochatku-vijny.

Отримано 10.09.21 